\title{
PASSAGEM FORÇADA E SERVIDÃO DE TRÂNSITO: LIMITAÇÕES DISTINTAS AO DIREITO DE PROPRIEDADE
}

\section{Marcéli da Silva Serafim ${ }^{1}$}

Resumo: Este artigo científico trata da distinção entre passagem forçada e servidão de trânsito, institutos compreendidos no direito das coisas. A servidão de trânsito constitui direito real de gozo sobre coisa alheia e deriva, na maioria das vezes, de acordo entre as partes, ao passo que a passagem forçada é restrição involuntária, infligida pela lei, dizendo respeito à falta de saída de um prédio para a via pública, exigindo-se, portanto, o encravamento do prédio dominante.

Palavras-chave: Direito real. Direito de vizinhança. Servidão de trânsito. Passagem forçada.

\section{INTRODUÇÃO}

Versa este artigo sobre as dessemelhanças entre servidão de trânsito e passagem forçada. Ao contrário desta, cuja constituição é compulsória ao prédio vizinho, aquela geralmente se origina de um acordo de vontades e traduz direito real de gozo sobre coisa alheia, passível de usucapião, inclusive.

1 Aluna do Módulo III da Escola Superior da Magistratura do Estado de Santa Catarina (ESMESC). Advogada. Bacharela no curso de Direito pela Universidade do Sul de Santa Catarina (UNISUL). Especialista em Direito Público, Convênio FURB/FFM/AMC/ESMESC. E-mail: marceli.ss@terra.com.br 
A passagem forçada é direito de vizinhança, instituída pela lei, mediante cabal indenização apenas em favor do titular do prédio gravado, ao passo que a servidão de trânsito é estabelecida em favor de prédio não encravado. Nesta, não se cogita do encravamento.

No atual Código Civil, a disciplina jurídica dos direitos de vizinhança vem representada nos arts. 1.277 a 1.313, divididos em sete seções, a saber: do uso anormal da propriedade; das árvores limítrofes; da passagem forçada; da passagem de cabos e tubulações; das águas; dos limites entre prédios e do direito de tapagem; e do direito de construir. As servidões, por sua vez, estão disciplinadas nos arts. 1.378 a 1.388 , do aludido diploma legal.

É evidente que este trabalho não tem a veleidade de pretender exaurir o tema, bastando para os fins colimados deste artigo o estudo perfunctório da passagem forçada e da servidão de caminho, institutos que, a despeito de pertencerem ao direito das coisas, possuem natureza diversa.

Este artigo científico está dividido em três partes: a primeira tratará dos direitos reais; a segunda dos aspectos relativos à passagem forçada, características, requisitos e extinção; e a terceira da servidão de trânsito, características, classificação, modos de aquisição, defesa em juízo e extinção.

\section{DIREITOS REAIS: BREVES CONSIDERAÇÕES}

Os direitos reais traduzem um conjunto de normas reguladoras das relações jurídicas referentes às coisas suscetíveis de apropriação pelo homem, segundo uma finalidade social.

Os direitos reais são típicos e encontram-se enumerados no art. 1.225 do vigente Código Civil, a saber:

Art. 1.225. São direitos reais: I - a propriedade; II - a superfície; III - as servidões; IV - o usufruto; V - o uso; VI - a habitação; VII - o direito do promitente comprador do imóvel; VIII - o penhor; IX - a hipoteca; X - a anticrese; XI - a concessão de uso especial para fins de moradia; XII - a concessão de direito real de uso (BRASIL, 2002, grifo meu). 
São características dos direitos reais: legalidade ou tipicidade, ou seja, os direitos reais encontram-se enumerados no art. 1.225 do vigente Código Civil, acima transcrito; taxatividade, isto é, os direitos reais não podem ser ampliados pela simples vontade das partes; publicidade, mormente em relação aos bens imóveis porque se submetem ao sistema formal de registro, que lhes imprime essa característica; eficácia erga omnes, uma vez que os direitos reais são oponíveis a todas as pessoas, indistintamente; aderência, pois o direito real acompanha a coisa em todas as suas mutações; direito de sequela, que confere ao titular de um direito real o direito de perseguir a coisa e reavê-la do poder de quem quer que injustamente a possua ou detenha, como consequência da característica anterior.

A propriedade, definida no art. 1.228 do atual Código Civil, traduz direito real (art. 1.225, I) sobre coisa própria e confere ao seu titular a faculdade de usar, gozar (fruir), dispor e o direito de reivindicar a coisa do poder de quem quer que injustamente a possua ou detenha. Trata-se, pois, de direito complexo.

São limitações legais ao direito de propriedade os direitos de vizinhança, conjunto de regras que disciplina a convivência harmônica entre os vizinhos, no qual se insere o direito à passagem forçada, que será objeto de estudo em item à parte.

Em face dessa exposição lacônica acerca dos direitos reais, já é possível compreender melhor as diferenças entre passagem forçada e servidão de caminho, tratadas com mais vagar nas páginas seguintes.

\section{PASSAGEM FORÇADA: DIREITO DE VIZINHANÇA}

O direito à passagem forçada é assegurado ao proprietário de prédio rústico, ou urbano, que estiver encravado em outro, sem acesso para a via pública, nascente ou porto. $\mathrm{O}$ direito à passagem forçada, na disciplina dos direitos de vizinhança, é regulado pelo Código Civil de 2002 no artigo 1.285.

Realmente, dispõe o art. 1.285 do Código Civil de 2002 que:

O dono do prédio que não tiver acesso a via pública, nascente ou porto, pode, mediante pagamento de indenização cabal, constranger o vizinho 
a lhe dar passagem, cujo rumo será judicialmente fixado, se necessário. $\S 1^{\circ}$. Sofrerá o constrangimento o vizinho cujo imóvel mais natural e facilmente se prestar à passagem. $§ 2^{\circ}$. Se ocorrer alienação parcial do prédio, de modo que uma das partes perca o acesso a via pública, nascente ou porto, o proprietário da outra deve tolerar a passagem. $§ 3^{\circ}$. Aplica-se o disposto no parágrafo antecedente ainda quando, antes da alienação, existia passagem através de imóvel vizinho, não estando o proprietário deste constrangido, depois, a dar uma outra (BRASIL, 2002).

$\mathrm{O}$ artigo em estudo corresponde ao art. 559 do Código Civil de 1916, contendo, todavia, significativas alterações, especialmente em seus três parágrafos, que agora indicam e disciplinam qual dos vizinhos será constrangido a dar a passagem.

A passagem forçada é imposta pela lei. Cuida-se de "servidão legal" que não se confunde com direito real de servidão. "Isso porque: a) decorre da lei e não do negócio jurídico; b) não se constitui pelo registro imobiliário, ao contrário do direito real de servidão; c) funda-se na necessidade e não na mera conveniência” (PELUSO, 2009, p. 1255).

\subsection{Características e Requisitos}

Cuida-se a passagem forçada de direito potestativo ou facultativo - por isso não sujeito à prescrição - de um vizinho exigir do outro o acesso à via pública, porto ou nascente, mediante indenização cabal. O vizinho é obrigado a admiti-la desde que concorram os seguintes requisitos: a) o encravamento deve ser absoluto, ou seja, não há acesso possível para a via pública, nascente ou porto; b) que o prédio seja naturalmente encravado, ou seja, não provocado pelo próprio requerente; c) a passagem é onerosa e somente exercida mediante pagamento de indenização cabal ao vizinho prejudicado.

A doutrina diverge no que se refere ao primeiro requisito. Gomes (2004, p. 235) ensina que "o encravamento deve ser 
natural e absoluto. Se forçado pelo proprietário do terreno, a este não assiste direito a reclamar passagem. Se dispõe de qualquer acesso, ainda penso, também não pode exigir o caminho". Diniz (2004, p. 261) não diverge ao destacar que "o encravamento é requisito básico. Somente o prédio que não tenha acesso para a rua, nascente ou porto ou qualquer logradouro público é que o tem, mas o seu encravamento terá de ser absoluto".

Gonçalves (2006, p. 335), acompanhando os autores acima citados, afirma que "não se considera encravado o imóvel que tenha outra saída, ainda que difícil e penosa. Razões de comodidade não são atendidas, para obrigar o vizinho a suportar a passagem por seu imóvel".

Corrente mais progressista e afinada com a função social da propriedade e o espírito do Código Civil de 2002, porém, afirma que cabível é a passagem forçada quando a única via de acesso se apresenta sumamente onerosa, impraticável ou perigosa, só utilizável à custa de imensos sacrifícios.

Nesse sentido, é o entendimento de Bessone (1996, p. 247):

Pelo texto do art. 559 percebe-se que o encravamento resulta da falta de saída para a via pública, fonte ou porto. Entende-se, todavia, como encravado também o prédio que tenha saída deficiente, incapaz de atender razoavelmente às necessidades do prédio. Será encravado, ainda, o prédio que somente tiver saída em certos períodos do ano. Não se reputará encravado, todavia, quando a saída pretendida for apenas mais cômoda. Nesse caso, a lei não impõe a concessão da passagem, podendo, segundo as regras aplicáveis, ocorrer a servidão de trânsito.

O Enunciado n. 88 da Comissão de Estudos Judiciários (CEJ) adotou a segunda corrente, mais social e mais humana: "O direito de passagem forçada previsto no art. 1.285 do Código Civil também é garantido nos casos em que o acesso à via pública for insuficiente ou inadequado, consideradas inclu- 
sive as necessidades de exploração econômica”.

A jurisprudência reflete essa divergência, ora exigindo o encravamento absoluto do imóvel ora se contentando com a excessiva dificuldade ou onerosidade de acesso já existente à via pública.

O Tribunal Catarinense já decidiu que assiste ao requerente o direito à passagem forçada na hipótese de encravamento predial, absoluto ou relativo, inclusive (Apelação Cível n. 2007.054900-8, de Rio do Sul, Rel. Desa. Maria do Rocio Luz Santa Ritta, j. em 30-04-2009).

Da jurisprudência do Superior Tribunal de Justiça (STJ), colhe-se:

CIVIL. DIREITOS DE VIZINHANÇA. PASSAGEM FORÇADA (CC, ART. 559). IMÓVEL ENCRAVADO. Numa era em que a técnica da engenharia dominou a natureza, a noção de imóvel encravado já não existe em termos absolutos e deve ser inspirada pela motivação do instituto da passagem forçada, que deita raízes na supremacia do interesse público; juridicamente, encravado é o imóvel cujo acesso por meios terrestres exige do respectivo proprietário despesas excessivas para que cumpra a função social sem inutilizar o terreno do vizinho, que em qualquer caso será indenizado pela só limitação do domínio (STJ-3a T., REsp. n. 316.336/MS, Rel. Min. Ari Pargendler, j. 18-08-2005, grifo meu).

O dispositivo do Código Civil (art. 1.285) em exame diz ainda que a passagem, se não houver consenso entre as partes, é fixada judicialmente, ainda que a ela se oponha o vizinho. $\mathrm{O}$ rumo é estabelecido pelo juiz na falta de acordo, sempre levando em conta, para fixação de trajeto e largura, a menor oneração possível do prédio serviente e a finalidade do caminho. $\mathrm{O}$ juiz deverá valer-se de perícia para essa apuração. Nada, porém, que substitua sua própria inspeção judicial. Essa inspeção, regulada pelo Código de Processo Civil, principalmente no exame de questões de posse e propriedade, é eficientíssima, pois permite 
ao magistrado examinar pessoalmente o local e tirar suas conclusões (VENOSA, 2008).

No que se refere ao juízo de necessidade, no qual deve se apoiar o direito à passagem forçada, convém destacar:

$\mathrm{O} \S 1^{\circ}$ do artigo em estudo positivou regra que já era utilizada pelos tribunais ao estabelecer uma escala de prioridade de escolha, fundada no critério da maior facilidade do acesso, levando em conta a localização e as características naturais dos prédios vizinhos. Logo, cabe exceção ao vizinho demandado, alegando que outro prédio proporciona maior facilidade de acesso ao imóvel encravado (PELUSO, 2009, p. 1256).

Essa limitação de passagem imposta ao vizinho não é gratuita. Cuida-se a passagem forçada de servidão legal onerosa, ou seja, o início de seu exercício está subordinado ao prévio pagamento de indenização cabal, a ser fixada judicialmente se não houver acordo entre as partes. "Essa indenização levará em conta a diminuição de valor da propriedade pela passagem de terreno alheio e a moléstia por ela ocasionada. Independe de culpa e decorre simplesmente do direito de vizinhança" (VENOSA, 2008, p. 284).

"A indenização se qualifica como cabal, abrangendo não somente todos os transtornos e incômodos decorrentes da passagem como também obras e cercas que se façam necessárias para assegurar a incolumidade do remanescente" (PELUSO, 2009, p. 1256).

Tal direito corresponde a uma desapropriação compulsória, no interesse particular, pois o proprietário do prédio onerado com a passagem tem o direito à indenização cabal, expressamente prevista no art. 1.285 do Código Civil. "O ressarcimento representa a compensação outorgada ao dono do imóvel por onde se estabelecer a travessia, pelos incômodos a que se sujeitará" (MONTEIRO, 2003, p. 142). 


\subsection{Extinção da Passagem Forçada}

Extingue-se a passagem forçada quando desaparece a sua causa, ou seja, quando o prédio deixa de ser encravado. "A limitação imposta ao prédio serviente só se justifica, efetivamente, em função da necessidade imperiosa de seu vizinho. Cessada tal necessidade, desaparece a razão para a permanência do aludido ônus" (GONÇALVES, 2006, p. 336).

De acordo com as lições de Venosa (2008, p. 284), o direito à passagem forçada traduz "direito potestativo ou facultativo, perdurando enquanto existir o encravamento. Cessado este, por qualquer razão, desaparece o direito de passagem. Nada impede, porém, que as partes constituam servidão sobre o que era direito legal de passagem".

$O$ direito à passagem forçada não se confunde com a servidão de passagem ou de trânsito: "a passagem forçada constitui modalidade onerosa do direito de vizinhança, cujo pressuposto é o encravamento do imóvel; juridicamente, encravado é o imóvel cujo acesso exige do respectivo proprietário despesas excessivas" (STJ-3a T., REsp. n. 850.867/PR, Rel. Min. Ari Pargendler, j. 26-08-08). Por sua vez, a servidão de trânsito traduz direito real sobre coisa alheia, imposto voluntariamente ou por usucapião ao prédio serviente em favor do prédio dominante.

\section{SERVIDÃO DE TRÂNSITO: DIREITO REAL SOBRE COISA ALHEIA}

O Código Civil de 1916 adjetivava as servidões com o vocábulo prediais, a fim de distingui-las das servidões pessoais, por tradição à origem histórica, uma vez que "as servidões no Direito Romano, em seu período mais recente, como direitos reais sobre coisas alheias, dividiam-se em servidões pessoais e servidões prediais" (VENOSA, 2008, p. 427).

$\mathrm{O}$ atual Código reporta-se unicamente ao título "servidões”. Nas palavras de Monteiro (2003, p. 276), definem-se servidões "como restrições impostas a um prédio para uso e utilidade de outro prédio, pertencente a proprietário diverso". 
Dispunha o art. 695 do Código Civil de 1916:

Impõe-se a servidão predial a um prédio em favor de outro, pertencente a diverso dono. Por ela perde o proprietário do prédio serviente o exercício de alguns de seus direitos dominicais, ou fica obrigado a tolerar que dele se utilize, para certo fim, o dono do prédio dominante (BRASIL, 1916).

Por seu lado, descreve o vigente Código no art. 1.378:

A servidão proporciona utilidade para o prédio dominante, e grava o prédio serviente, que pertence a diverso dono, e constitui-se mediante declaração expressa dos proprietários, ou por testamento, e subsequente registro no Cartório de Registro de Imóveis (BRASIL, 2002).

O atual Código Civil, ao disciplinar a matéria, deu redação mais técnica às características da servidão, eliminando-se o termo "impõe-se", que dava a falsa impressão de ser a servidão compulsória ao prédio serviente, aproximando-a da passagem forçada do direito de vizinhança.

Parafraseando Bessone (1996), o termo prédio não significa construção, mas terreno, que pode ter ou não acessões. $\mathrm{O}$ prédio que sofre as restrições é o serviente, e o que recebe vantagens e utilidades é o dominante.

O Código Civil atual, como alhures destacado, ao contrário do Código Civil de antanho, não usa a expressão "servidão predial”, mas tão somente servidão. Para efeito doutrinário, não se confundem o direito real de servidão, ora estudado, e as inadequadamente apelidadas "servidões legais", que nada mais são do que restrições gerais ao direito de propriedade. Estas últimas, segundo Pereira (2004, p. 275 e 276):

São criadas pelo legislador no propósito de instituir a harmonia entre vizinhos e compor os seus conflitos. Originam-se do imperativo da lei, ao passo que as servidões são encargos que um prédio sobre em favor de outro, de forma a melhorar o aproveitamento ou utilização do beneficiado. 
Segundo o escólio de Monteiro (2003, p. 277), "efetivamente, servidão tem como pressuposto a existência de dois prédios distintos, o serviente e o dominante". São, portanto, elementos da servidão: dois prédios distintos; diversidade dominial; relação de serviço ou utilidade.

"As servidões podem tomar as mais variadas formas. A mais conhecida é a servidão de trânsito ou de passagem, que assegura ao proprietário de um imóvel a prerrogativa de transitar pelo imóvel de outrem" (GONÇALVES, 2006, p. 422, destacado no original).

Está descrito no art. 1.378 do atual Código Civil um dos mais antigos institutos jurídicos. A servidão de trânsito pressupõe a existência de dois prédios vizinhos (não necessariamente contíguos) pertencentes a proprietários diversos. Diz-se serviente o prédio sujeito à servidão e dominante o que dela se beneficia. "Interessante notar que a servidão não cinde a propriedade; exerce-se sobre a propriedade de outrem, ambas permanecendo íntegras" (VENOSA, 2008, p. 429).

Venosa (2008, p. 429), citado repetidas vezes neste estudo em face das suas brilhantes lições, destaca que "vantagem e restrição, portanto, em matéria de servidão, formam dois aspectos correlativos. Essa correlação estabelece-se com índole real e não sob aspecto transitório e pessoal”.

\subsection{Características}

A servidão é direito real, imobiliário, sobre coisa alheia, e acessório. Segundo Bessone (1996, p. 278):

É real porque estabelece um poder jurídico direto e imediato sobre a coisa, isto é, um poder que não depende da intermediação do proprietário do prédio serviente: é jus in re, não é ad rem. É imobiliário, porque se liga necessariamente às coisas imóveis. É sobre coisa alheia, porque não se admite servidão sobre coisa própria. É acessório, porque não se o concebe independentemente do prédio dominante, ao qual se prende (destacado no original). 
Ainda acerca das características das servidões:

Algumas regras regem o direito real de servidão. É direito real e acompanha o imóvel em todas suas transmissões; é inalienável, por não admitir transferência separada do prédio a que adere, em razão de sua natureza acessória. É direito que se exerce, mas inalienável: pode ser alienado o prédio gravado ou beneficiado pela servidão, mas não o direito real em si mesmo considerado, pois não se constitui servidão sobre servidão. A servidão não se presume, porque a propriedade se presume plena. Logo, a servidão deve ser provada de modo explícito, e sua interpretação é sempre restritiva, quanto a sua existência ou extensão, e seu exercício deve ser o menos oneroso ao prédio serviente (PELUSO, 2009, p. 1401).

A servidão é uma relação entre dois prédios distintos, pertencentes a diversos proprietários: o prédio serviente sofre as restrições em favor do outro, o prédio dominante. "Como direito real que é, a servidão grava um dos prédios e o acompanha nas mutações por que venha a passar, até que se extinga por uma das causas legais" (GONÇALVES, 2006, p. 423). "As servidões estabelecem-se nos prédios em prol dos proprietários (ou possuidores, enfiteutas, usufrutuários etc.), presentes e futuros" (VENOSA, 2008, p. 429).

Como direitos acessórios, as servidões acompanham os prédios quando alienados. Nesse sentido, diz-se que as servidões tendem à perpetuidade. "Direito real na coisa alheia, visto que onera prédios, independentemente das pessoas a que pertençam, o ônus adere à coisa e a acompanha em todas as transferências do seu domínio, opondo-se erga omnes" (GOMES, 2004, p. 320). A servidão tem caráter acessório, uma vez que se liga a um direito principal, que é o direito de propriedade que lhe dá origem. Desta acessoriedade decorrem a inalienabilidade, a indivisibilidade e a perpetuidade, que são seus atributos inerentes. A servidão é perpétua, no sentido de que tem duração indeterminada, porém, nada impede que se 
constitua por tempo determinado, ou sob condição. Vencido o prazo estabelecido para sua duração ou ocorrido o adimplemento da condição ela se extingue. Alguns autores, contudo, referem que a servidão "dura indefinidamente, enquanto não extinta por alguma causa legal, ainda que os prédios passem a outros donos" (GONÇALVES, 2006, p. 424). De acordo com o estrênuo autor, perde a característica de servidão quando estabelecida por tempo determinado.

Sua indivisibilidade está contida no art. 1.386 do vigente Código Civil, que assim preceitua:

As servidões prediais são indivisíveis, e subsistem, no caso de divisão dos imóveis, em benefício de cada uma das porções do prédio dominante, e continuam a gravar cada uma das do prédio serviente, salvo se, por natureza, ou destino, só se aplicarem a certa parte de um ou de outro (BRASIL, 2002).

"A servidão estabelece-se por inteiro, gravando o prédio serviente no seu todo, sendo um ônus uno e indiviso, que não pode ser partilhado" (DINIZ, 2004, p. 380). A servidão é indivisível porque não se desdobra em caso de divisão do prédio dominante ou do prédio serviente. Significa dizer que a servidão não se adquire nem se perde por partes, pois comprometeria sua causa.

Segundo a doutrina de Monteiro (2003, p. 278 e 279), do princípio da indivisibilidade resultam as seguintes consequências:

a) a servidão não pode ser instituída em favor de parte ideal do prédio dominante, nem pode incidir sobre parte ideal do prédio serviente; b) se o proprietário do imóvel dominante se torna condômino do serviente, ou vice-versa, mantémse a servidão; c) defendida a servidão por um dos condôminos do prédio dominante, a todos aproveita a ação.

A servidão é inalienável, ou seja, o dono do prédio dominante não pode cedê-la ou transferi-la a outrem, pois implicaria extinção da antiga servidão e constituição de outra. "Não 
se pode, assim, de uma servidão constituir outra. O dono do prédio dominante não tem direito de estendê-la ou ampliá-la a outras propriedades" (GONÇALVES, 2006, p. 425).

A servidão não se presume, pois se constitui mediante declaração expressa dos proprietários, ou por testamento, e subsequente registro no Cartório de Registro de Imóveis (CC, art. 1.378). Nesse sentido, a expressão legal: "a servidão não se presume” (art. 696 do Código Civil de 1916), não repetida pelo vigente ordenamento. A dicção da lei traz regra fundamental a reger as servidões. A servidão deve ser comprovada de modo explícito, cabendo o ônus da prova (CPC, art. 333, I) a quem alega sua existência. No conflito de provas, apresentadas pelo autor e pelo réu, decide-se, na dúvida, contra a servidão. Sua interpretação é sempre restrita, por implicar limitação ao direito de propriedade.

Venosa (2008, p. 438) doutrina que "o domínio presumese pleno, sem ônus ou gravames. As servidões somente podem ser estabelecidas pelas formas admitidas em lei. São vistas como exceção à regra geral de domínio". Ainda, de acordo com as lições do autor, "atos de mera tolerância de proprietário com relação a vizinho não têm o condão de originar servidão", pois "não induzem posse os atos de mera permissão ou tolerância assim como não autorizam a sua aquisição os atos violentos, ou clandestinos, senão depois de cessar a violência ou a clandestinidade" (CC, art. 1.208).

Vale ratificar que as servidões são estabelecidas voluntariamente, por acordo entre os proprietários de ambos os prédios. Impostas coativamente pela lei, constituem as chamadas servidões legais (direitos de vizinhança). A simples utilidade ou mera facilidade é causa para instituição da servidão, pois prescinde do encravamento do imóvel.

\subsection{Classificação}

Comportam as servidões diversas classificações. A mais antiga classificação divide-as em urbanas e rústicas. Mas tal 
distinção perdeu o interesse, dada sua pouca importância prática. Venosa (2008, p. 432) distingue-as:

Como servidões urbanas devem ser entendidas as que se referem à utilidade de um prédio edificado e não porque localizadas na zona urbana. $O$ critério da distinção coloca-se na natureza da servidão. Rurais são as que proporcionam maior utilidade ao solo do imóvel.

No dizer sempre expressivo de Gomes (2004, p. 321):

As servidões classificam-se pela sua causa, objeto e modo de exercício. Considerada a causa, dividemse em servidões legais, naturais e voluntárias; o objeto, em servidões urbanas e rurais; pelo modo de exercício, classificam-se em três grupos: $1^{\circ}$ ) positivas e negativas; $2^{\circ}$ ) contínuas e descontínuas; $3^{\circ}$ ) aparentes e não aparentes.

Segundo o autor supracitado (p. 321), “a classificação das servidões pela causa ou origem é admitida em algumas legislações e repelida em outras". São legais as servidões que advêm de imposição legal (p. ex.: passagem forçada), por isso são restrições à propriedade similares à servidão. As naturais são as que derivam da situação dos prédios (p. ex.: a que se verifica em relação ao escoamento das águas) e convencionais são as que resultam de convenção entre os proprietários dos prédios dominante e serviente.

A mais importante classificação das servidões é a que as distingue pelo modo de exercício. Servidões afirmativas (positivas) são as que possibilitam um comportamento positivo do titular do prédio dominante, como a servidão de trânsito; as negativas implicam abstenção ao titular do prédio serviente, como a proibição de construir além de certa altura.

Podem ser continuas ou descontinuas (não contínuas): as contínuas exercitam-se constantemente, dispensam atos humanos para que subsistam e sejam exercidas, como a de passagem de 
água; as descontínuas são as que dependem, para seu exercício, de comportamento humano, como a servidão de passagem. Podem ser aparentes ou não aparentes: as aparentes são as que se revelam por obras ou sinais exteriores, constatáveis icto oculi, como a de passagem marcada no terreno; não aparentes são as que não têm sinal externo de sua existência.

Essas espécies de servidão podem ser combinadas, dando origem, então, às servidões contínuas e aparentes, como as de aqueduto; às contínuas e não aparentes, como as de não construir além de certa altura; às descontínuas e aparentes, como as de trânsito por caminho marcado no terreno; às descontínuas e não aparentes, como as de tirar água, sem caminho visível.

Importante distinguir as servidões aparentes das não aparentes, uma vez que essa distinção se refere à exteriorização do direito real. "Se é certo que todas elas podem ser constituídas, por acordo de vontades, somente as servidões contínuas e aparentes se estabelecem pela usucapião" (GOMES, 2004, p. 322 e 323). "Somente as servidões aparentes podem ser adquiridas por usucapião, regra que está presente, aliás, no art. 1.379 do corrente Código" (VENOSA, 2008, p. 433).

São denominadas irregulares as servidões que não implicam limitações a um prédio em favor de outro, mas limitação a prédio em favor de determinada pessoa, como a de colher frutos em prédio alheio (MONTEIRO, 2003).

\subsection{Modos de Aquisição}

Cinco são os modos de aquisição do direito real de servidão: a) por negócio jurídico inter vivos levado ao registro imobiliário; b) por negócio jurídico causa mortis, em testamento; c) por destinação do proprietário; d) por decisão judicial, em ação divisória; e) por usucapião.

O primeiro modo de aquisição, por negócio jurídico bilateral inter vivos, tem forma solene, sempre escrita, por escritura pública, se de valor superior a trinta salários mínimos, ou por instrumento particular em caso contrário (CC, art. 108). Como 
se trata de direito real sobre imóvel, é exigida a outorga uxória ou marital, salvo se o regime de bens do casamento for o da separação absoluta.

O registro é constitutivo do direito real, servindo o contrato como título. "Desse modo, os modos de constituição mencionados servem apenas como títulos ou pressupostos à aquisição do direito real de servidão. Este só nasce, como referido, com o aludido registro" (GONÇALVES, 2006, p. 427).

Gomes (2004, p. 327), a esse respeito, observa que:

A convenção, isto é, o acordo de vontades, é o modo mais comum de constituição das servidões prediais. Mas, em verdade, deve ser tomado antes como fonte do que modo de constituição propriamente dito. De fato. A servidão é um direito real imobiliário. Ora, entre nós, os direitos reais sobre imóveis não se constituem senão pelo competente registro. Os contratos produzem apenas efeitos obrigacionais; geram obrigações; não têm força para criar direito real.

Pode a servidão ser instituída por testamento (CC, art. 1.378 , in fine), caso em que o testador institui servidão sobre o prédio que deixa a algum beneficiário, que receberá sua propriedade gravada em favor de outro prédio.

Embora a constituição de servidão por decisão judicial não se encontre prevista no Código Civil, há expressa menção no art. 979, II, do Código de Processo Civil. Ao efetuar a demarcação dos quinhões na ação divisória, poderá o juiz instituir as servidões indispensáveis de uns quinhões sobre outros, especialmente no caso de encravamento.

Constituem-se também as servidões por usucapião, desde que reunidos os pressupostos legais, mencionados no art. 1.379 e parágrafo único do vigente Código Civil. Referido artigo prescreve que:

O exercício incontestado e contínuo de uma servidão aparente, por dez anos, nos termos do art. 1.242, autoriza o interessado a registrála em seu nome 
no Registro de Imóveis, valendo-lhe como título a sentença que julgar consumado a usucapião. Parágrafo único. Se o possuidor não tiver título, o prazo da usucapião será de vinte anos (BRASIL, 2002).

Impende observar que a palavra "consumado" deveria estar no feminino, concordando com usucapião, que o Código trata como substantivo feminino.

Para a usucapião ordinária exige-se, portanto, justo título e posse incontestada e contínua por dez anos. $\mathrm{O}$ parágrafo único supratranscrito, que cuida da usucapião extraordinária, reclama, todavia, prazo maior, ou seja, vinte anos, mas dispensa o título.

O legislador não foi razoável ao estabelecer prazo de usucapião extraordinária de vinte anos para constituir servidão, pois segundo Gonçalves (2006, p. 429):

O Código Civil aperfeiçoou a redação do dispositivo, ficando explicitado que a usucapião abrange a servidão aparente. Todavia, houve uma falha no que tange ao requisito temporal, uma vez que o mais longo prazo de usucapião deveria ser o de quinze anos, que é o da prescrição extraordinária (CC, art. 1.238). Mas foi fixado em vinte, no aludido parágrafo único, mesmo sabendo-se que a servidão é apenas parcela da propriedade.

O Enunciado n. 251 da CEJ chegou à mesma conclusão: "O prazo máximo para o usucapião extraordinário de servidões deve ser de 15 anos, em conformidade com o sistema geral de usucapião previsto no Código Civil".

No que se refere à posse, elemento básico à prescrição aquisitiva, Gonçalves (2006, p. 429), diz que "a exigência de que a servidão seja aparente decorre do próprio conceito que àquela é atribuído. Sendo definida como exteriorização do domínio, a sua configuração supõe a visibilidade, a publicidade, que inexiste na servidão não aparente".

O mesmo autor (p. 430) assinala ainda que "a servidão não aparente, devido à falta de visibilidade da posse, e a descon- 
tínua, devido ao uso intermitente, como no caso da servidão de trânsito, não autorizam o reconhecimento da prescrição aquisitiva”. Todavia, a jurisprudência passou a admitir, somente com relação às servidões de passagem, embora descontínuas, a proteção possessória, desde que se revelem por sinais exteriores, como resulta da Súmula n. 415 do Supremo Tribunal Federal (STF): "Servidão de trânsito não titulada, mas tornada permanente, sobretudo pela natureza das obras realizadas, considerase aparente, conferindo direito à proteção possessória”.

Sobre a destinação do proprietário, modo constitutivo de servidão não previsto em nosso ordenamento, Diniz (2004, p. 388) observa que:

A servidão pode ser instituída por destinação do proprietário no caso de a mesma pessoa ter dois prédios e, criada uma serventia visível de um em benefício do outro, venham mais tarde a ter donos diversos em virtude de alienação ou herança, criando-se, então, uma servidão, sem a manifestação formal do instituidor, porém originária de um ato de vontade unilateral do proprietário.

Ou, por outras palavras, "dá-se a constituição por destinação do proprietário, quando este estabelece uma serventia em favor de um prédio sobre outro, sendo ambos de sua propriedade, e um deles é alienado" (GONÇALVES, 2006, p. 430).

Esse modo de constituição das servidões subordina-se, segundo a lição de Monteiro (2003, p. 282), ao concurso de três requisitos: "a) o estado visível da coisa, existência de obras que revelem a destinação; b) a separação dos dois prédios, que passam a pertencer a proprietários diferentes; c) a falta de declaração contrária ao estabelecimento da servidão”.

Além dos modos de constituição anteriormente enumerados, existe ainda, relativamente à servidão de trânsito, modo especial decorrente de fato humano. Assim, se "o dono do prédio dominante costuma servir-se de determinado caminho aberto no prédio serviente, e se este se exterioriza por sinais visíveis, como aterros, mata-burros, bueiros, pontilhões etc., nasce 
o direito real sobre coisa alheia, digno de proteção possessória" (GONÇALVES, 2006, p. 432). Trata-se de modalidade revelada pela jurisprudência.

O exercício das servidões está disciplinado nos arts. 1.383 e 1.385 do Código Civil de 2002, regras que determinam os direitos e deveres recíprocos dos proprietários do prédio dominante e do serviente. A esse respeito, Ruggiero (1999, p. 665) afirma:

São todas elas dominadas por estes princípios capitais: que em primeiro lugar deva vigorar na regulamentação da relação a livre vontade das partes e que entre a causa da liberdade e da sujeição deva, na dúvida, ser preferida a primeira, como mais vantajosa ao interesse geral. A norma fundamental, é pois, que o conteúdo e os limites dos poderes pertencentes ao titular da servidão, como a extensão das limitações ou das obrigações positivas que incidem sobre o proprietário do prédio serviente são determinados pelo título ou pela posse.

\subsection{Defesa em Juízo}

No direito brasileiro, as ações que amparam as servidões são as seguintes: a) confessória; b) negatória; c) possessória; d) de nunciação de obra nova; e) de usucapião.

"As servidões se estabelecem em juízo por ação confessória; negam-se por ação negatória e defendem-se por ação possessória”, ensina Rizzardo (2006, p. 918).

A ação confessória visa à obtenção do reconhecimento judicial da existência de servidão, quando negada, ou contestada pelo proprietário do prédio gravado. Em assonância com a lição sempre precisa de Gomes (2004, p. 330), "o titular do direito real de servidão defende-o por meio da ação que tem por fim o reconhecimento judicial do seu direito, se contestado pelo dono do prédio serviente". Cuida-se a ação confessória de via ainda pouco explorada no cotidiano forense. 
Por sua vez, a ação negatória destina-se a possibilitar ao dono do prédio serviente a obtenção de sentença que declare a inexistência de pretensa servidão ou de direito à sua ampliação. É ajuizada contra aquele que, sem título, objetiva ter servidão sobre o imóvel, ou, então, almeja ampliar direitos já existentes. $\bigcirc$ fundamento encontra-se na existência da propriedade livre e na lesão, que impede o autor de exercer o domínio pleno. $\mathrm{O}$ art. 1.228 do atual Código Civil contém a sua razão maior: ao proprietário é conferida a faculdade de usar, gozar e dispor da coisa, e o direito de reavê-la do poder de quem quer que injustamente a possua ou detenha.

Em favor do dono do prédio dominante, que é molestado ou esbulhado pelo proprietário do prédio serviente, é conferida a proteção possessória. Alguns autores sustentam ser cabível somente a ação de manutenção de posse, por não se consumar a perda do próprio imóvel. Contudo, tem a jurisprudência admitido a possibilidade de esbulho.

A ação de nunciação de obra nova visa a defender a servidão tigni immittendi (meter trave na parede do vizinho), com fundamento no art. 934, I, do Código de Processo Civil.

Por fim, a ação de usucapião, conforme expresso no art. 1.379 do Código Civil.

\subsection{Extinção da Servidão de Trânsito}

Sem embargo da perpetuidade, cessa a servidão: a) pela confusão, uma vez que a servidão pressupõe pluralidade de prédios pertencentes a proprietários diversos, desaparecendo quando passam a um só domínio; b) pela convenção; c) pela renúncia; d) pelo não uso; e) pela impossibilidade de exercício em decorrência de mudança de estado dos lugares, que ocorre, por exemplo, quando, sendo a servidão de tirar água, a fonte seca; f) pelo perecimento; g) pela resolução do domínio de quem as constitui; h) pelo decurso do prazo quando constituída a termo, pelo implemento de condição ou pela desapropriação. 
Extinguindo-se a servidão, cabe ao interessado promover o cancelamento do registro de seu título constitutivo, exceto se houver desapropriação, porque nesse caso a extinção se dá pleno iure, mediante o próprio ato expropriatório (CC, art. 1.387). Em se tratando de perecimento do objeto, dá-se a cessação ex re ipsa, e, sendo assim, igualmente independe de cancelamento do registro, porque desaparece com ou sem este.

\section{CONCLUSÃo}

Não é rara a confusão entre passagem forçada e servidão de trânsito. A passagem forçada decorre da lei e é imposta no interesse social. A servidão de caminho decorre da vontade das partes, e não da lei, e visa a aumentar a comodidade e utilidade do imóvel dominante em detrimento do serviente, não estando condicionada, portanto, ao encravamento daquele imóvel.

De lembrar, pois, que a passagem forçada pressupõe um prédio encravado, com indispensável necessidade de saída para a via pública, assegurando ao proprietário do prédio dominante o direito de consegui-la sobre prédios alheios, possibilitando-lhe a destinação econômica e social. Já a servidão de trânsito é instituída convencionalmente, na maioria das vezes, e não requer a inexistência de outro caminho para atingir-se um prédio distinto ou a via pública.

$\mathrm{Ou}$, por outras palavras, a passagem forçada, direito de vizinhança, funda-se na necessidade e na indispensabilidade, ao passo que a servidão de trânsito, direito real de gozo sobre coisa alheia, coloca-se no cômodo e até no supérfluo.

A servidão de trânsito distingue-se da passagem forçada, porque esta é imposta por lei mediante cabal indenização apenas em favor do titular do prédio onerado. Cuida-se de ato lícito que gera indenização. Por sua vez, a servidão de trânsito pode ser estabelecida em favor de prédio não encravado, apenas para tornar mais cômoda a utilização do prédio dominante. Em epítome, apesar de ambos os institutos pertencerem ao direito das coisas, sua equiparação é um desacerto. 


\begin{abstract}
This article deals with the scientific distinction between forced passage and transit easement, two institutes included in the discipline of the right of things. The transit easement is the real right of enjoyment over someone else's thing and it derives in most cases, from an agreement between the parties, whereas the forced passage is an involuntary restriction, inflicted by law, concerning the non existence of exit from one building to a public way - for such it is required that the dominant estate is stuck.
\end{abstract}

Keywords: Real right. Right of neighbourhood. Transit easement. Forced passage.

\title{
REFERÊNCIAS
}

BRASIL. Constituição (1988). Constituição da República Federativa do Brasil: promulgada em 5 de outubro de 1988. Disponível em: <http://www. planalto.gov.br/ccivil_03/Constituicao/Constituiçao.htm>. Acesso em: 24 de maio de 2010.

. Lei n. 3.071, de 1o de janeiro de 1916. Código Civil. Disponível em: <http://www.planalto.gov.br/ccivil_03/Leis/L3071.htm>. Acesso em: 2 de junho de 2010.

. Lei n. 10.406, de 10 de janeiro de 2002. Institui o Código Civil. Disponível em: <http://www.planalto.gov.br/ccivil_03/LEIS/2002/L10406. htm>. Acesso em: 24 de maio de 2010.

. Lei n. 5.869, de 11 de janeiro de 1973. Institui o Código de Processo Civil. Disponível em: <http://www.planalto.gov.br/ccivil_03/LEIS/L5869. htm>. Acesso em: 29 de maio de 2010.

Superior Tribunal de Justiça. CIVIL. DIREITOS DE VIZINHANÇA. PASSAGEM FORÇADA (CC, ART. 559). IMÓVEL ENCRAVADO.

Numa era em que a técnica da engenharia dominou a natureza, a noção de imóvel encravado já não existe em termos absolutos e deve ser inspirada pela motivação do instituto da passagem forçada, que deita raízes na supremacia do interesse público; juridicamente, encravado é o imóvel cujo acesso por meios terrestres exige do respectivo proprietário despesas excessivas para que cumpra a função social sem inutilizar o terreno do vizinho, que em qualquer caso 
será indenizado pela só limitação do domínio. Recurso especial conhecido e provido em parte. Recurso Especial n. 316.336. Recorrente: Ayrton Teixeira . Recorridos: Antônio Pereira Neto e cônjuge. Relator Min. Ari Pargendler, Mato Grosso do Sul, 18 de agosto de 2005. Disponível em: <http://www.stj.jus.br/ webstj/processo/Justica/detalhe.asp?numreg=200100393560\& pv=0100000000 00\& tp=51>. Acesso em: 24 de maio de 2010 .

Superior Tribunal de Justiça. CIVIL. DIREITOS DE VIZINHANÇA. PASSAGEM FORÇADA. IMÓVEL ENCRAVADO. A passagem forçada constitui modalidade onerosa do direito de vizinhança, cujo pressuposto é o encravamento do imóvel; juridicamente, encravado é o imóvel cujo acesso exige do respectivo proprietário despesas excessivas. Recurso especial conhecido e provido em parte. Recurso Especial n. 850.867. Recorrente: Altevir Riesemberg Filho e cônjuge. Recorridos: Plínio Altair Pan e outro. Relator Min. Ari Pargendler, Paraná, 26 de agosto de 2008. Disponivel em: <http://www.stj.jus. $\mathrm{br} /$ webstj/processo/Justica/detalhe.asp? numreg $=200600875790 \& \mathrm{pv}=0100000$ 00000\& tp $=51>$. Acesso em: 24 de maio de 2010.

. Supremo Tribunal Federal. Súmula n. 415. SERVIDÃO DE TRÂNSITO NÃO TITULADA, MAS TORNADA PERMANENTE, SOBRETUDO PELA NATUREZA DAS OBRAS REALIZADAS, CONSIDERA-SE APARENTE, CONFERINDO DIREITO À PROTEÇÃO POSSESSÓRIA. Disponível em: <http://www.stf.jus.br/ portal/cms/verTexto.asp?servico=jurisprudenciaSumula\& pagina $=$ su mula_401_500>. Acesso em: 30 de maio de 2010.

BESSONE, Darcy. Direitos reais. 2. ed. São Paulo: Saraiva, 1996. 499 p.

DINIZ, Maria Helena. Curso de direito civil brasileiro: direito das coisas. 19. ed. rev., aum. e atual. São Paulo: Saraiva, 2004. v. 4, 584 p.

GOMES, Orlando. Direitos reais. 19. ed. rev., atual. e ampl. Rio de Janeiro: Forense, 2004. 496 p.

GONÇALVES, Carlos Roberto. Direito civil brasileiro: direito das coisas. São Paulo: Saraiva, 2006. v. 5, 620 p.

MONTEIRO, Washington de Barros. Curso de direito civil: direitos das coisas. 37. ed. rev. e atual. São Paulo: Saraiva, 2003. v. 3, 469 p.

PELUSO, Cezar (Coord.). Código civil comentado. 3. ed. rev. e atual. Barueri, SP: Manole, 2009. 2387 p. 
PEREIRA, Caio Mário da Silva. Instituições de direito civil: direitos reais. 18. ed. Rio de Janeiro: Forense, 2004. v. 4, 467 p.

RIZZARDO, Arnaldo. Direito das coisas. 2. ed. Rio de Janeiro: Forense, 2006. 1178 p.

RUGGIERO, Roberto de. Instituições de direito civil: direito de família, direitos reais e posse. Tradução de: Paolo Capitanio. Campinas: Bookseller, 1999. v. 2, 822 p.

SANTA CATARINA. Tribunal de Justiça de Santa Catarina. AÇÃO DE NUNCIAÇÃO DE OBRA NOVA. INTERESSE DE MENORES. PARTICIPAÇÃ̇O DO MINISTÉRIO PÚBLICO EM PRIMEIRO GRAU. FALTA SUPRIDA POR PARECER DA PROCURADORIA DE JUSTIÇA. NULIDADE ARREDADA. [...] A intervenção do Ministério Público em segundo grau de jurisdição, sem arguir nulidade nem prejuízo, supre a falta de intervenção do Parquet na primeira instância, não acarretando a nulidade do processo (STJ - Resp n. 439.955, Rel. Min. Sálvio de Figueiredo Teixeira). MÉRITO. CONSTRUÇÃO DE MURO NA DIVISA DE IMÓVEIS LINDEIROS. OBSTRUCCÃO AO ACESSO DE UM DELES PELOS FUNDOS. SERVIDÃO. INEXISTÊNCIA DO DIREITO REAL. PASSAGEM FORÇADA. AUSÊNCIA DE TAL OBRIGAÇÃO NA HIPÓTESE, ANTE ACESSO EXTENSO PELA FRENTE DO IMÓVEL. UTILIZAC̣ÃO DA ÁREA POR ATO DE MERA TOLERÂNCIA DOS RÉUS, FRUTO DE COMODATO CELEBRADO COM OS AUTORES. OBRIGAÇÃO DE PERMANÊNCIA INEXISTENTE. AÇÃO IMPROCEDENTE. SENTENÇA MANTIDA. RECURSO DESPROVIDO. Não havendo encravamento predial, absoluto ou relativo, a justificar a passagem forçada como direito de vizinhança (art. 559, CC/16), tampouco inexistindo prova de servidão de passagem a legitimar o atravessadouro (art. 694, CC/16), a transposição pelo imóvel vizinho resulta de mera permissão ou tolerância, cabendo assim o seu fechamento pelos réus. Apelação Cível n. 2007.054900-8. Apelantes: Marli Chiquetti Haag e outro. Apeladas: Annete Ohf e outro. Relatora Desa. Maria do Rocio Luz Santa Ritta. Rio do Sul, SC, 30 de abril de 2009. Disponível em: < http://www.tj.sc.gov.br/>. Acesso em: 24 de maio de 2010.

VENOSA, Sílvio de Salvo. Direito Civil: direitos reais. 8. ed. São Paulo: Atlas, 2008. v. 5, 626 p. 